\title{
Viva Video Development Using Local Wisdom for Improving The Quality of English Learning
}

\author{
Normalasarie, Noormaliah \\ STKIP PGRI Banjarmasin \\ Banjarmasin, Indonesia \\ normala.sari142@gmail.com
}

\begin{abstract}
Media development based on local wisdom to use application of viva video aimed to produce viable instructional media used in learning that is active, innovative, creative, effective and fun. This study used an ASSURE models through six stages, namely analyzing learning, stating objectives, selecting methods, media, and materials, requiring learner participation, evaluating and revising. The study involved 30 junior high school students of VII class in individual testing, small group piloting and large group trial. The study involved 30 junior high school students of class VII. The data were collected from subject matter experts, media experts, and the students. The instruments for data collection were questionnaires and tests of learning. The results of the study showed the assessment of display, attractiveness, language, and operation aspects. The aspect of display obtained $80 \%$ responses indicating a very viable and feasible display. Attractiveness aspect obtained 86.6\%. The aspect of language was considered highly decent with $96.6 \%$ responses from 29 students out of 30 . Further, operation aspect was considered decent and qualified as indicated by the average value of $93.3 \%$ responses. The use of media is very effective related to the mastery level of factual knowledge, concepts, and procedural learning.
\end{abstract}

Keywords-Media Development, Local Wisdom, ASSURE Models

\section{INTRODUCTION}

This in teaching and learning process, communication will not run well when the message delivered by teachers is hard to understand. Learning process will be effective and efficient if teachers can create good atmosphere in the classroom. To create it, teachers should have good communication and some media to support their activities.

Media in teaching and learning process will support the effectiveness of learning [1]. It means that media really help teachers in delivering their materials.

In choosing media, teachers should consider the students' learning styles. There are four learning styles, namely visual, audio, visual and audio and kinaesthetic. Based on this consideration, teachers can create teaching and learning process more effectively and efficiently.

Since Indonesian government have released 18 values in education or national characters in 2011, teachers should consider and involve these on their material and media especially nation characters number 16 . It discusses about environment. This demands school parties to ask teachers, students and all elements to give attention to their environment. It means that teachers should create the material and media based on local wisdom.

Based on the Indonesian English syllabus, the students at seventh grade should master English texts, such as descriptive text and procedure text. In this case, teachers need to create material based on the local wisdom. SMP Darul Hijrah Putra is located in Cindai Alus Martapura, a farming area, so the English teachers should design the text especially Procedure text based on the background of Cindai Alus. Cindai Alus has produced cassava and people in this place make it as crisp.

Even though environment has been issued in education but in reality not all teachers create their material and media based local wisdom. It will be a hindrance for students to understand the material. That is why teachers need to involve local wisdom in their material. The benefits are that students care not only about environment but they also understand the material easily because the material has been created based on their background knowledge. In this study, the researchers discussed the development of learning medium by using Viva video to support teachers to create teaching and learning process based on local wisdom.

\section{THEORETICAL REVIEW}

The use of multiple media formats for the presentation of information includes texts, still or animated graphics, movie segments, video, and audio information [2]. Computer-based interactive multimedia includes hypermedia and hypertext. Hypermedia is a computer-based system that allows interactive link of multimedia format including text, still or animated segments, video, and audio. Hypertext is non-linear organized and accessed screens of text and static diagrams, pictures, and tables.

Multimedia is the digital integration of text (written), graphic (the interface of the program), audio (dialog, stories, sound effect), still images (pictures and visual stimuli), and motion video [3]. Through the integration of all these media, the learning experience becomes an interactive one mirroring everyday experiences. In this study, viva video was discussed to help the teachers to design a medium that can help them to 
deliver their material. Viva video is an application video maker and video editor. This application has been designed specially for smartphone.

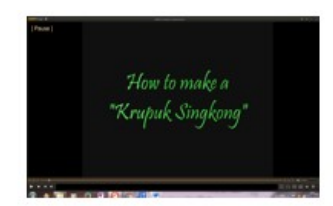

e.g. How to make cassava crisp by using Viva Video

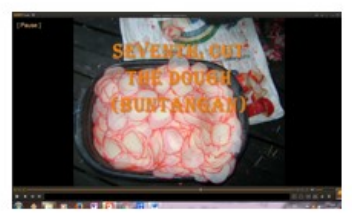

e.g The process of making cassava crisp

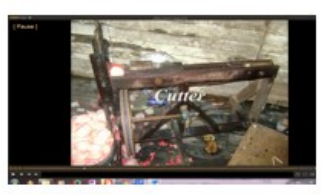

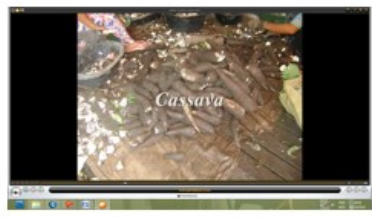

e.g The Ingredients for making cassava crisp

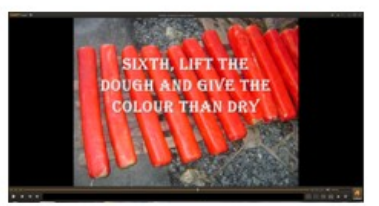

Fig. 1. Viva Video

Local wisdom is in the form of certain principles and ways adopted, understood, and applied by the local community in interacting with the environment and transformed in the form of customary value system and norms [4]. Ref [5] stated that local wisdom refers to knowledge that comes from community experiences and this is accumulated from local knowledge. Local wisdom can be in society, community and individual.

\section{METHOD}

This study used research and development (R\&D) with assure model. Learning medium by using assure model was designed by using problem solving approach and it has been arranged systematically with 6 steps: analyzing learner; stating standards and objectives; selecting strategies, technology, media and materials; requiring learners' participation; evaluating and revising. These steps are as follows: (1) Identifying students' characteristic. The media planning is based on students' needs. The indicators of students' needs are students' ability, skill and affective which they should master: (2) Formulating objective. The learning media should help students to achieve their learning goal; (3) Selecting, changing, and designing learning media. Getting appropriate learning media usually has 3 possibilities, namely selecting the available learning media, trying to revise the available learning media, and designing new learning media; (4) Formulating materials. The material should relate to English subject; (5) Requiring learners' participation. Teacher should require the students in applying the media; (6) Evaluating. The evaluation goals were to select the media used in the class, to check procedure in applying the media, to check whether the media was utilized well or not, to assess teacher in applying the media, to give some information for administration and to fix the media itself.

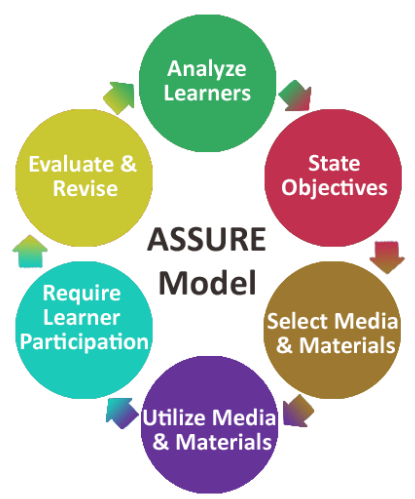

Fig.2. Assure Model

The setting of this study was at SMP Darul Hijrah Putra. It is located on Jalan Cindai Alus Martapura, Banjar region. This study was conducted in academic year 2015/2016. This study involved 30 seventh grade students.

The qualitative and quantitative data were used in this study. The data were described qualitatively. Qualitative data came from media experts, material expert and students, while quantitative data came from questionnaire score. To analyze the questionnaire data about the students' opinion, percentage technique was used [6].

\section{RESUlT AND DiscUSSION}

This section describes the results of developing the learning medium by using Viva video application. The results consisted of the material expert's assessment, media expert's assessment and questionnaire.

\section{A. Results}

The results of the material expert's assessment on the material in Viva video can be seen below.

TABLE I. THE RESUlt OF MATERIAL EXPERT'S ASSESSMENT

\begin{tabular}{|c|c|c|c|}
\hline No & Assessment Criteria & Assessment & Explanation \\
\hline 1 & $\begin{array}{l}\text { How do the researchers analyze } \\
\text { students' characteristic? }\end{array}$ & $100 \%$ & Excellent \\
\hline 2 & $\begin{array}{l}\text { How do the researchers select the } \\
\text { medium accurately? }\end{array}$ & $80 \%$ & Good \\
\hline 3 & $\begin{array}{l}\text { Does the material match the } \\
\text { learning objectives? }\end{array}$ & $100 \%$ & Excellent \\
\hline 4 & Is it an appropriate medium? & $80 \%$ & Good \\
\hline 5 & $\begin{array}{l}\text { In learning process, does the teacher } \\
\text { utilize the material well? }\end{array}$ & $80 \%$ & Good \\
\hline 6 & $\begin{array}{l}\text { How does this activity engage the } \\
\text { students in learning process? }\end{array}$ & $80 \%$ & Good \\
\hline 7 & $\begin{array}{l}\text { Have the researchers made } \\
\text { evaluation? }\end{array}$ & & Done \\
\hline 8 & Have the researcher made revision? & & Done \\
\hline
\end{tabular}


TABLE II. THE RESUlt OF MEDIA EXPERT'S ASSESSMENT

\begin{tabular}{|c|l|c|}
\hline No & \multicolumn{1}{|c|}{ Assessment Criteria } & Assessment \\
\hline & Visual Element & \\
& Presenter performances in this medium & $100 \%$ \\
& Player performance in this medium & $60 \%$ \\
& Shooting location based on the message & $80 \%$ \\
& Visual lighting system in video & $80 \%$ \\
& & \\
& Sound Element & $80 \%$ \\
& Visual clarity in video & $80 \%$ \\
& Player's clarity voice in video & $80 \%$ \\
& Utilizing music in video & $80 \%$ \\
\hline
\end{tabular}

Tabel III, IV, V, and VI shows the data from product trial on seventh grade students of SMP Darul Hijrah Putra. The following data have been collected based on 4 aspects, namely display, attractiveness, language and operation.

TABLE III. The STUDENTS' RESPONSES ON DisPlay ASPECT OF THE MEDIUM

\begin{tabular}{|c|c|c|}
\hline Qualitication & Frequency & Percentage \\
\hline Very reasonable & 24 & $80 \%$ \\
Reasonable & 6 & $20 \%$ \\
Unreasonable & - & - \\
Very unreasonable & - & - \\
\hline$\Sigma$ & 30 & $100 \%$ \\
\hline
\end{tabular}

Based on the data, there were 24 students who stated the display of the learning medium was very reasonable and 6 students who stated the display was reasonable. No responses for unreasonable and very unreasonable options were found.

TABLE IV. The StUdENTS' ReSPONSES ON ATtRaCtIVENESS ASPECT OF THE MEDIUM

\begin{tabular}{|c|c|c|}
\hline Qualitication & Frequency & Percentage \\
\hline Very attractive & 21 & $70 \%$ \\
Attractive & 5 & $16.6 \%$ \\
Unrattractive & 4 & $13.3 \%$ \\
Very unattractive & - & - \\
\hline$\Sigma$ & 30 & $100 \%$ \\
\hline
\end{tabular}

Based on the data of learning medium attractiveness, the majority of the students regarded that the learning medium was attractive $(86,6 \%)$, as indicated by 21 students and 5 students who opted very attractive and attractive options, respectively. However, there were 4 students who selected unattractive option for the medium attractiveness.

TABlE V. The Students' Responses on Language Aspect of the MEDIUM

\begin{tabular}{|c|c|c|}
\hline Qualitication & Frequency & Percentage \\
\hline Very good & 18 & $60 \%$ \\
Good & 11 & $36.6 \%$ \\
Poor & 1 & $3.3 \%$ \\
Very poor & - & - \\
\hline$\Sigma$ & 30 & $100 \%$ \\
\hline
\end{tabular}

Based on the students' response on the language aspect, 29 out of 30 students viewed the language in the medium was already good $(96.6 \%)$. There was one student who considered the language poor $(3.3 \%)$.

TABLE VI. THE STUDENTS' RESPONSES ON OPERATION ASPECT OF THE MEDIUM

\begin{tabular}{|c|c|c|}
\hline Qualitication & Frequency & Percentage \\
\hline Very reasonable & 20 & $66 \%$ \\
Reasonable & 8 & $26.6 \%$ \\
Unreasonable & 2 & $7.4 \%$ \\
Very unreasonable & - & - \\
\hline$\Sigma$ & 30 & $100 \%$ \\
\hline
\end{tabular}

Based on Table VI, it is known that 28 out of 30 students stated that the operation of the medium was worthy qualification with an average value of $93.4 \%$. Moreover, there were 2 students who considered that the operation was not feasible with the average value of $7.4 \%$.

\section{B. Discussions}

Viva video learning provides local knowledge-based videos to develop English language teaching for junior high school students. Viva video development covered the syllabus, lesson plan (RPP in Indonesian context), and achievement test. The learning medium was integrated with local wisdom of Cindai Alus Martapura and the development of the English language for students.

The developed learning medium has been validated by experts to assess the quality of the medium. The expert validation on the medium demonstrated positive results on the display, attractiveness, language and operation aspects. Thus, the quality of the medium was good. Major revision was not suggested, which means that images, audio, video, animation, language and operation were already appropriate.

This medium might be effective for other basic competencies that have identical characteristics. The medium might also be effective for other subjects other than English language that have similar indicator. Learning by using this medium will enable students to learn more effectively because they can learn the material individually. This is in line with the Ref [1] that instructional media will support the effectiveness of learning.

With the development of instructional media on an ongoing basis based on local wisdom are expected not only to improve students' cognitive aspects but also to develop students' character. Sustainable principle is very important because if it is done continuously through character education, students will be familiar with the local wisdom and gradually students' habit will be formed into a positive state. This is in line with ref [4] that local wisdom transforms the value system and norm. 


\section{CONCLUSION}

This study has produced a local wisdom-based learning medium to develop positive character of students. Learning tools to complement the medium include the syllabus, lesson plan and achievement test. The learning medium was integrated with local wisdom at Cindai Alus area, Martapura. The medium was developed to integrate the character development of students. The learning medium has been validated by experts, so it is proper for use.

\section{REFERENCES}

[1] A. Arsyad, Media Pembelajaran, Jakarta: PT Raja Grafindo Persada, 2009.

[2] S. Hackbarth, The Educational Technology Handbook: A Comprehensive Guide: Process and Product For Learning, Englewood Cliffs, New Jersey: Educational Technology Publications, 1996.

[3] T. Vaughan, Multimedia: Making It Work (w/CD) (8th Ed), New York: McGraw-Hill, 2001.

[4] K. Kongprasertamon, "Local wisdom, environmental protection and community development: the clam farmers in tabon bungkhusai, phetchaburi province thailand," Journal of Humanities, vol. 10, pp. 1-10, 2007., 1992.

[5] Zulkarnain and R. Febriamansyah, "Kegiatan lokal dan pemanfaatan dan pelestarian sumberdaya pesisir," Jurnal Agribisnis Kerakyatan, vol. 1, pp. 69-85, 2008.

[6] S. Arikunto, Dasar-Dasar Evaluasi Pendidikan, Jakarta: PT. Bina Aksara 